\title{
Cytotoxic granule secretion by lymphocytes and its link to
}

\section{immune homeostasis [version 1; peer review: 2 approved]}

\author{
Geneviève de Saint Basile ${ }^{1-3}$, Fernando E. Sepulveda1,2, Sophia Maschalidi1,2, \\ Alain Fischer1,2,4,5 \\ ${ }^{1}$ INSERM UMR1163, Laboratory of Normal and Pathological Homeostasis of the Immune System, Paris, F-75015, France \\ 2Paris Descartes University-Sorbonne Paris Cité, Imagine Institute, Paris, F-75015, France \\ ${ }^{3}$ Centre d'Etudes des Déficits Immunitaires, Assistance Publique-Hôpitaux de Paris, Assistance Publique-Hôpitaux de Paris, Paris, \\ France \\ ${ }^{4}$ Immunology and Pediatric Hematology Department, Necker Children's Hospital, AP-HP, Paris, France \\ ${ }^{5}$ Collège de France, Paris, F-75005, France
}

V1 First published: 30 Sep 2015, 4(F1000 Faculty Rev):930

https://doi.org/10.12688/f1000research.6754.1

Latest published: 30 Sep 2015, 4(F1000 Faculty Rev):930

https://doi.org/10.12688/f1000research.6754.1

\begin{abstract}
The granule-dependent cytotoxic activity of $\mathrm{T}$ and natural killer lymphocytes has progressively emerged as an important effector pathway not only for host defence but also for immune regulation. The analysis of an early-onset, severe, primary immune dysregulatory syndrome known as hemophagocytic lymphohistiocytosis (HLH) has been decisive in highlighting this latter role and identifying key effectors on the basis of gene mutation analyses and mediators in the maturation and secretion of cytotoxic granules. Studies of cytotoxicitydeficient murine counterparts have helped to define primary HLH as a syndrome in which uncontrolled T-cell activation in response to lymphocytic choriomeningitis virus infection results in excessive macrophage activation and inflammation-associated cytopenia. Recent recognition of late-onset $\mathrm{HLH}$, which occurs in a variety of settings, in association with hypomorphic, monoallelic mutations in genes encoding components of the granule-dependent cytotoxic pathway or even in the absence of such mutations has broadened our view about the mechanisms that underlie the perturbation of immune homeostasis. These findings have led to the development of a model in which disease occurs when a threshold is reached through the accumulation of genetic and environmental risk factors. Nevertheless, validation of this model will require further investigations.
\end{abstract}

Keywords

haemophagocytic lymphohistiocytosis , cytotoxic, natural killer

lymphocytes

\section{Open Peer Review}

Approval Status

1

2

version 1

30 Sep 2015

1. Loïc Dupré, INSERM, UMR1043, Toulouse, France

\section{Ilia Voskoboinik, Peter MacCallum Cancer}

Centre, East Melbourne, Australia

Any comments on the article can be found at the end of the article. 
Corresponding author: Geneviève de Saint Basile (genevieve.de-saint-basile@inserm.fr)

Competing interests: The authors declare that they have no competing interests.

Grant information: The author(s) declared that no grants were involved in supporting this work.

Copyright: @ 2015 de Saint Basile G et al. This is an open access article distributed under the terms of the Creative Commons Attribution License, which permits unrestricted use, distribution, and reproduction in any medium, provided the original work is properly cited.

How to cite this article: de Saint Basile G, Sepulveda FE, Maschalidi S and Fischer A. Cytotoxic granule secretion by lymphocytes and its link to immune homeostasis [version 1; peer review: 2 approved] F1000Research 2015, 4(F1000 Faculty Rev):930

https://doi.org/10.12688/f1000research.6754.1

First published: 30 Sep 2015, 4(F1000 Faculty Rev):930 https://doi.org/10.12688/f1000research.6754.1 


\section{Granule-dependent cytotoxic activity is a key regulator of immune homeostasis}

The role of cytotoxic lymphocytes in defending the organism against virally infected cells and tumor cells has long been recognized. Through the polarized secretion of granules containing cytotoxic proteins, cytotoxic lymphocytes can rapidly kill their cognate target cells ${ }^{1}$. However, only recently have studies of inherited deficiencies of lymphocyte cytotoxic activity in humans highlighted the importance of lymphocyte cytotoxicity in the resolution of inflammation ${ }^{2}$.

Hemophagocytic lymphohistiocytosis (HLH) syndrome is a lifethreatening immune dysregulation condition characterized by an excessive inflammatory response and hypercytokinemia. It is generally triggered by an infective agent, such as the members of the human herpes virus family. HLH manifests as the massive expansion and activation of polyclonal $\mathrm{CD}^{+} \mathrm{T}$ cells; this probably results from the failure of cytotoxic T lymphocyte (CTL) and natural killer (NK) cells to clear antigen-presenting cells (APCs) and therefore terminate an immune response $\mathrm{e}^{3,4}$. Uncontrolled T-cell activation leads to macrophage activation, a pro-inflammatory cytokine storm, cytopenia, coagulopathy, multi-organ cellular infiltration, and organ dysfunction $^{5-7}$. The link between cytotoxicity and lymphocyte homeostasis was first demonstrated 15 years ago, following the identification of perforin deficiency in a subgroup of patients with an inherited form of HLH (familial HLH, or FHL) ${ }^{2}$. Undoubtedly, this step was decisive in the characterization of the other causes of inherited HLH and in the identification of key effectors that mediate the exocytic machinery in cytotoxic lymphocytes ${ }^{8,9}$. Naturally occurring or engineered mice with a similar cytotoxicity defect have proven to be very useful tools for further understanding the underlying pathophysiological mechanism ${ }^{4,10,11}$. The observation that a relatively mild cytotoxic defect can be associated with defective immune surveillance or atypical HLH onset or both has now raised the question of the underlying individual's risk factors that are associated with a subtle cytotoxic defect to drive disease onset.

\section{Studies of inherited defects of cytotoxicity have revealed critical effectors of cytotoxic granule exocytosis}

The sequence of events by which T/NK cytotoxic lymphocytes kill targets is now fairly well characterized. When cytotoxic lymphocytes recognize their cognate target cells, they form a transient cellular conjugate and an immunological synapse (IS) at the area of cell-cell contact $^{1,12}$. Within the very first minutes of target cell interaction, the actin network, which was previously positioned across the entire contact area, is progressively depleted from the center of the synapse, as recently highlighted by the use of rapid, super-resolution imaging methods ${ }^{13-15}$. The microtubule-organizing centre (MTOC) rapidly moves toward the target cell, while the cytotoxic granules (containing the cytotoxic proteins perforin and granzymes) migrate along microtubules and cluster around the $\mathrm{MTOC}^{8,16}$. At the IS, the centrosome can touch the membrane and then deliver polarized cytotoxic granules ${ }^{17}$. The granules fuse with the presynaptic membrane and secrete their contents into the synaptic cleft. This accurate, polarized secretion of lytic reagents ensures that cytotoxic cells destroy only the bound target cell and not bystander cells. Within the synaptic cleft, perforin oligomerizes, creates pores in the target cell membrane, and thus enables the pro-apoptotic granzymes to access the target cytosol ${ }^{18-20}$. The mechanism of granzyme uptake has long been subject to debate. By using time-lapse microscopy techniques that pinpoint the moment at which perforin permeabilizes the target cell plasma membrane within the IS, researchers observed that the time course of target cell apoptosis after pore formation is very rapid (that is, within $10 \mathrm{mins})^{21,22}$. In contrast to what has been proposed in other studies ${ }^{23-25}$, this suggests that granzymes cross the plasma membrane and are not taken up in endosomes.

In addition to perforin deficiency ${ }^{2}$, which accounts for about one third of the FHL cases, several inherited forms of HLH are characterized by failure to deliver cytotoxic granule contents. The identification of the underlying molecular causes has contributed to our understanding of the key steps in the secretion of cytotoxic granules at the IS ${ }^{8}$. Biallelic mutations in UNC13D (encoding Munc13-4, accounting for about one third of FHL cases), STX11 (encoding syntaxin 11, about 5\% of FHL cases), and STXBP2 (encoding syntaxin-binding protein 2, also known as Munc18-2, about 20\% of FHL cases) led to the occurrence of HLH in FHL types 3, 4, and 5, respectively ${ }^{26-29}$. In about $10 \%$ of FHL cases, the molecular defect remains uncharacterized. Biallelic mutations in RAB27A (encoding the small GTPase Rab27a) and LYST (encoding lysosomal trafficking regulator) account for the development of HLH in Griscelli syndrome ${ }^{30}$ and Chédiak-Higashi syndrome $^{31}$, respectively. Remarkably, each of these molecules mediates a discrete, non-redundant step in cytotoxic granule exocytosis at the IS. Rab27a and Munc13-4 are respectively required for the granule docking and priming steps at the plasma membrane, whereas syntaxin 11 interacts with Munc18-2 to enable granules to fuse with the plasma membrane ${ }^{8}$. Although the role of LYST is less well understood, it may regulate a late granule maturation $s^{32}{ }^{32}$. The effector molecules' partners and interconnections have been progressively characterized to reveal the overall picture of granule exocytosis. Notably, interaction between Rab27a and Munc13-4 was shown to be mandatory for tethering the cytotoxic granules at the IS in order to complete the exocytic process ${ }^{33}$. Munc13-4 interacts with several syntaxin isoforms, among them syntaxin $11^{34}$. Furthermore, Rab27a binds to three different members of the synaptotagmin-like (SLP1-3) family expressed in cytotoxic cells that have partially overlapping functions in granule transport and docking ${ }^{35-37}$.

It has been proposed that direct contact between polarized centrosomes and the plasma membrane drives cytotoxic granule delivery at the IS ${ }^{17,38}$. However, there is evidence to suggest that alternative mechanisms are involved, such as the observation that very rapid, effective cytotoxic granule secretion can precede MTOC polarization in some CTL-target cell conjugates ${ }^{39}$. In the latter study, inhibition of MTOC polarization did not prevent cytotoxic granule release. Furthermore, the Slp3/Rab27a complex expressed in cytotoxic cells was shown to interact with a kinesin motor and to mediate the terminal transport of polarized cytotoxic granules toward the IS $^{35}$. In view of the diversity of in vivo settings in which cytotoxic cells are triggered, one can legitimately hypothesize that granule delivery may occur via several different routes. Indeed, recent research has shown that cytotoxic cells are heterogeneous and change their killing performance over time and as a function of antigenic stimulation ${ }^{40,41}$. Timescale studies of single NK cells or CTLs have 
revealed a progressive increase in the rapidity and efficiency of killing during serial killing, which also varies according to the avidity of antigen recognition ${ }^{40,41}$. It remains not well understood how what has been shown in vitro applies in vivo, such as the nature of target cells and the strength of triggering signal.

\section{The use of animal models to characterize the pathophysiology of hemophagocytic lymphohistiocytosis} Animal models of primary HLH in which cytotoxicity-deficient mice are challenged with a virus have proven to be invaluable for understanding the pathogenesis of HLH under defined conditions. It has been demonstrated that after lymphocytic choriomeningitis virus (LCMV) infection of perforin-deficient mice, hyperactive CTLs and high levels of interferon-gamma (IFN- $\gamma$ ) are the driving forces behind the development of fatal $\mathrm{HLH}^{4}$. LCMV's potent induction of HLH might be due, at least in part, to its ability to infect APCs and thus strongly stimulate a T-cell response without the need for antigen cross-presentation. Likewise, Epstein-Barr virus (EBV), a major trigger of HLH in humans, can directly infect $B$ cells, which also have an antigen presentation function and trigger prolonged antigenic stimulation when not eliminated by cytotoxic lymphocytes. In addition to viral priming, antigen persistence and prolonged presentation were shown to be critical in the development of primary HLH in murine models ${ }^{4,10}$. This appears to contrast with the onset of primary HLH in newborn infants or even fetuses with cytotoxicity defects, since a pathogen trigger cannot be identified in many cases ${ }^{42,43}$. Although as-yet-unknown microorganisms may act as the trigger, this observation suggests that, in contrast to the situation in mice, the granule-dependent cytotoxic pathway in humans also has a role in T-cell homeostasis in the absence of an external stimulus (as is also the case for the Fas/FasL pathway). It has been shown that the elimination of a rare, antigen-presenting dendritic cell (DC) population by $\mathrm{CD}^{+} \mathrm{T}$ cells in a negative feedback loop is a critical determinant of the magnitude of T-cell responses ${ }^{44,45}$. Thus, the elimination of specific APC populations probably determines the activation status and survival of hyper-reactive $\mathrm{T}$ cells and acts as a rheostat by limiting T-cell responses. Whether the granuledependent cytotoxic pathway is also participating to check selfreactive T/B cells is therefore a possibility that needs to be further investigated.

In mice, the degree of cytotoxicity impairment appears to be the best predictor of the development and severity of HLH, as shown by studies of the time course of HLH onset in various HLH-prone strains with defects in the granule-dependent cytotoxic pathway ${ }^{10,46}$. The same is true in humans ${ }^{10,46}$ (Figure 1A). In genetically determined murine models of HLH, the cytotoxicity of both T cells and NK cells is impaired. However, in contrast to $\mathrm{CD} 8^{+} \mathrm{T}$-cell depletion, NK cell depletion in perforin-deficient mice did not prevent the development of manifestations of $\mathrm{HLH}^{4}$. CTLs were thus considered to be the main players in the development of HLH. However, recent work has revealed that $\mathrm{T}$ cells and NK cells have a non-redundant cytotoxic function in HLH: CTLs mediate LCMV viral clearance, whereas NK cells limit hyperactivation of CTLs ${ }^{11}$. This finding further suggests that the perforin-dependent cytotoxic activity of NK cells has a key role in the maintenance of immune homeostasis and the prevention of immunopathology $y^{47,48}$. However, the underlying mechanism through either direct or indirect T/NK cell interactions remains to be characterized. Furthermore, one cannot fully exclude the participation of other potentially cytotoxic cells such as invariant NK T (iNKT) cells and CD4 ${ }^{+} \mathrm{T}-$ cell subsets, including specific regulatory $\mathrm{T}$ (Treg) populations, in this setting. It is also worth noting that in syntaxin 11-deficient mice, which display a milder cytotoxic defect and less severe HLH than perforin-deficient mice, blockade of inhibitory receptors of T-cell exhaustion (such as PD1/PDL1) dramatically increases the severity of HLH and results in fatal disease ${ }^{49}$. This finding indicates that T-cell exhaustion is another important modulator of HLH severity.

The in vivo failure of cytotoxic cells to eliminate target cells leads to a fatal cytokine storm, a hallmark of HLH. Previous research has shown that the threshold of T-cell activation determines whether a lytic synapse (which is induced at low antigen concentrations and which enables cytotoxic activity) or a stimulatory synapse (induced at high antigen concentrations and which enables both cytotoxic activity and IFN- $\gamma$ production) is formed ${ }^{50}$. Remarkably, it was recently shown that cytotoxicity-deficient lymphocytes form longer contacts with their cognate target, thus resulting in many successive rounds of $\mathrm{Ca}^{2+}$ flux into cytotoxic cells and triggering of proinflammatory cytokine secretions ${ }^{51}$. Thus, the cytokine storm as observed in HLH likely depends on both quantity and quality of contacts formed between cytotoxic cells and APCs.

Phagocytosis of blood cells by macrophages (known as hemophagocytosis) is another hallmark of primary HLH, although it can be observed in a variety of infectious or inflammatory disorders ${ }^{52}$. A study of perforin-deficient mice has revealed that IFN- $\gamma$ specifically triggers this process, which can be reproduced in wild-type mice by inducing the sustained elevation of IFN- $\gamma$. Direct, IFN$\gamma$-dependent activation of macrophages prompts the development of severe, consumptive anemia and other types of cytopenia, probably through direct changes in the macrophages' endocytic uptake ${ }^{53}$. These results indicate that hemophagocytosis is actually an adapted response to sustained or severe inflammation. Further details on the role of macrophages and other inflammatory cells in the pathophysiology of HLH have been provided in recent reviews $\mathrm{s}^{5,6,54}$.

Although cytotoxic lymphocytes exert a key role in the development of primary HLH, other immune cells and signaling pathways may also contribute. It has been shown that MyD88, which mediates Toll-like receptor (TLR) and interleukin-1 (IL-1) signaling, is required for HLH development in Unc13d-deficient mice, suggesting that innate immune cells contribute to the development of $\mathrm{HLH}^{55}$. Moreover, high levels of IL-4 or repeated TLR9 stimulation in wild-type mice can induce the development of an HLH-like syndrome ${ }^{56,57}$. Hence, proteins from the cytotoxic exocytic pathway may have additional functions in other immune cell types (such as inflammatory cells), the absence of which modulates the pathogenesis of HLH. More generally, any regulatory molecule involved in an inflammatory pathway might contribute to the development of the manifestations of HLH. 
A

$\mathrm{HLH}$

severity

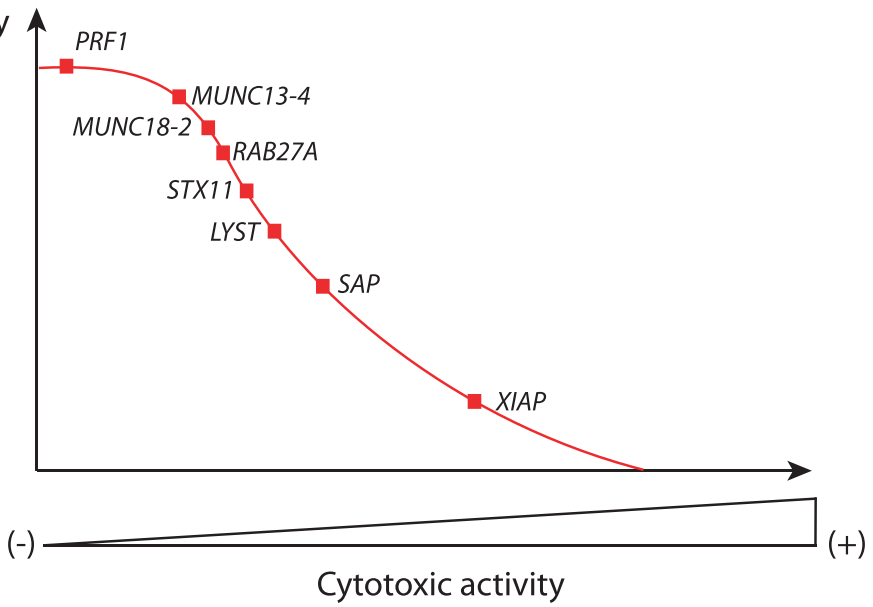

B

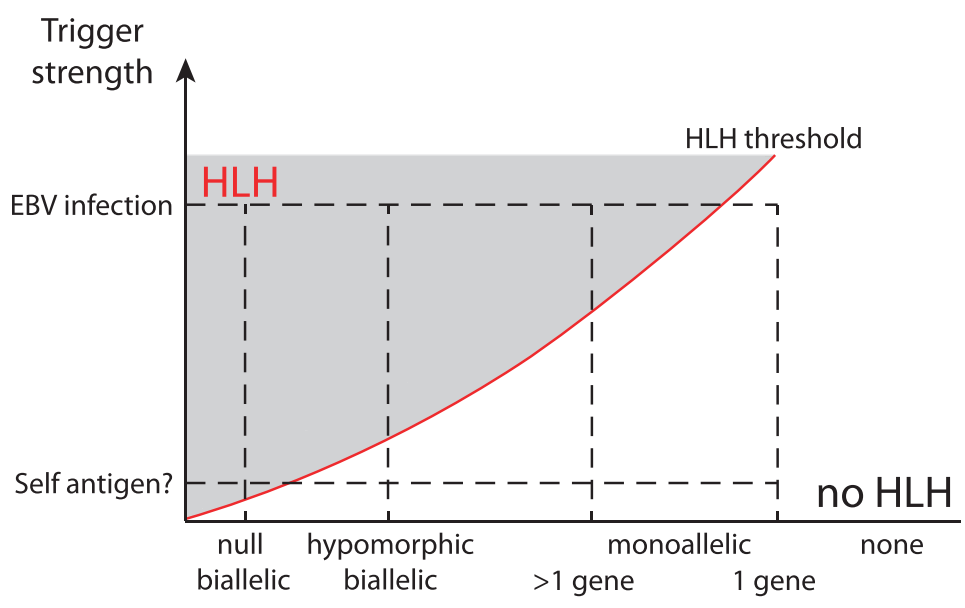

Genetic mutations in HLH genes

Figure 1. Impact of various genetic and environmental risk factors on threshold of hemophagocytic lymphohistiocytosis (HLH) development. (A) A gradient of hemophagocytic lymphohistiocytosis $(\mathrm{HLH})$ severity correlates with the defect in cytotoxic activity of lymphocytes that results from various genetic defects in humans and mice. Null mutations are considered in this image. (B) Evolving view of the risk factors inducing HLH development. Mild to extreme immune stimuli, in combination with severe (null) mutations, hypomorphic mutations, monoallelic mutation in several or one of the genes involved in $\mathrm{HLH}$, appear to determine an individual's risk for developing HLH. HLH risk lies above the red line in the hatched area.

\section{What is the minimum level of cytotoxic activity required to preserve immune homeostasis?}

Genetically determined forms of HLH can occur even when a cytotoxicity defect is only partial or apparently absent. This is the case in X-linked lymphoproliferative syndrome (XLP). Patients with XLP are extremely vulnerable to EBV infection and most go on to develop HLH ${ }^{58}$. There are two genetic forms: XLP-1 and XLP-2. Firstly, XLP-1 results from a deficiency in the signaling lymphocyte activation molecule (SLAM)-associated protein (SAP) ${ }^{59-61}$. SAPdeficient CTLs and NK cells are selectively impaired in their cytotoxic response to infected B cells; the response requires interaction between SLAM family receptors and subsequent SAP-dependent signaling in T lymphocytes but not in other cell types ${ }^{62,63}$. Secondly, XLP-2 results from a deficiency in the X-linked inhibitor of apoptosis protein (XIAP) (also known as BIRC4) ${ }^{64}$. However, XIAPdeficient CTLs and NK cells exhibit apparently normal in vitro cytotoxic responses (regardless of the SLAM-receptor dependency). The cytotoxic activity of iNKT cells is known to be activated by EBV-infected B cells ${ }^{65}$. Indeed, the exacerbated apoptosis of XIAP-deficient iNKT cells, induced by EBV infection, might 
be involved in the development of HLH in XLP-2. Alternatively, the mechanisms underlying EBV-driven HLH in XLP-2 may differ completely from those observed in XLP-1 and other inherited forms of HLH. In a setting of XIAP deficiency, the accumulation of apoptotic cells and the persistence of EBV-infected cells might trigger abnormal inflammation and contribute to the development of HLH. This hypothesis is supported by the observation that XIAP deficiency in mice results in excessive DC death and inflammasome activation $^{66}$

It is difficult to assess the minimal level of cytotoxic activity required for the maintenance of immune homeostasis. Hypomorphic mutations in HLH genes that preserve residual cytotoxicity significantly delay the onset of HLH but predispose patients to hematological cancers ${ }^{67-69}$. Adult patients with HLH have been found to carry a monoallelic mutation in one or more FHL genes $^{70-73}$. These findings suggest that the accumulation of heterozygous mutations that partially impair the granule-dependent cytotoxic pathway may have an additional functional impact. This hypothesis could be tested by studying inter-crossed animal models of HLH with monoallelic mutations. The concept whereby a monoallelic mutation in cytotoxicity-related genes can lead to immune disturbance also requires far more investigation, particularly in much larger cohorts of patients with induced HLH versus healthy controls. When the cytotoxicity defect is mild, the relative weight of additional genetic and environmental factors in HLH triggering is probably greater. It is tempting to speculate that (i) "extreme" stimuli may be sufficient to induce sporadic HLH development in any individual and (ii) the overall risk is augmented by the accumulation of genetic variants promoting excessive or poorly regulated immune response (Figure 1B). Along these lines, mutations in genes controlling inflammatory processes may also contribute to HLH. Recently, de novo activating mutations in the nucleotide-binding domain of inflammasome component NLRC4, associated with high levels of inflammatory cytokines in general and of IL-18 in particular, were found to be linked to recurrent $\mathrm{HLH}^{74-76}$. Since impaired cytotoxicity was not detected in that setting, this finding highlights the role of additional molecules in the pathophysiological process leading to HLH. By coupling next-generation sequencing to animal model studies, it should now be possible to determine whether HLH can be a polygenic condition in adults.

\section{Concluding remarks}

Over the last few decades, characterization of the molecular bases of primary HLH has highlighted the critical role of CTL activity in the control of immune homeostasis and has identified key effectors of cytotoxic granule exocytosis and their specific functions along the cytotoxic pathway. Broader knowledge of the scope of HLH occurrence has prompted the hypothesis whereby HLH is a "threshold" disease. A combination of both genetic factors and environmental factors (infections, self-antigens, and so on) is needed for the development of HLH in a context of residual cytotoxicity. Some cases of HLH do not appear to be directly related to a cytotoxicity defect, indicating that other genes, notably involved in macrophage-related inflammation, regulating the same disease pathway also have a role. Characterizing the synergistic connections between the various risk factors for HLH will be a key challenge in the coming years.

\section{Abbreviations}

APC, antigen-presenting cell; CTL, cytotoxic T lymphocyte; DC, dendritic cell; EBV, Epstein-Barr virus; FHL, familial hemophagocytic lymphohistiocytosis; HLH, hemophagocytic lymphohistiocytosis; IFN- $\gamma$, interferon-gamma; IL, interleukin; iNKT, invariant natural killer T; IS, immunological synapse; LCMV, lymphocytic choriomeningitis virus; MTOC, microtubule-organizing centre; NK, natural killer; SAP, signaling lymphocyte activation moleculeassociated protein; SLAM, signaling lymphocyte activation molecule; TLR, Toll-like receptor; XIAP, X-linked inhibitor of apoptosis protein; XLP, X-linked lymphoproliferative syndrome.

\section{Competing interests}

The authors declare that they have no competing interests.

\section{Grant information}

The author(s) declared that no grants were involved in supporting this work.
1. F Stinchcombe JC, Bossi G, Booth S, et al.: The immunological synapse of TL contains a secretory domain and membrane bridges. Immunity. 2001; 15(5): 751-61.

PubMed Abstract | Publisher Full Text | F1000 Recommendation

2. Stepp SE, Dufourcq-Lagelouse R, Le Deist $F$, et al: Perforin gene defects in familial hemophagocytic lymphohistiocytosis. Science. 1999; 286(5446): 1957-9. PubMed Abstract | Publisher Full Text

3. Kägi D, Seiler P, Pavlovic J, et al.: The roles of perforin- and Fas-dependent cytotoxicity in protection against cytopathic and noncytopathic viruses. Eur Immunol. 1995; 25(12): 3256-62. PubMed Abstract | Publisher Full Text

4. Jordan MB, Hildeman D, Kappler J, et al:: An animal model of hemophagocytic lymphohistiocytosis $(\mathrm{HLH})$ : $\mathrm{CD}^{+} \mathrm{T}$ cells and interferon gamma are essential for the disorder. Blood. 2004; 104(3): 735-43. PubMed Abstract | Publisher Full Text
5. Pachlopnik Schmid J, Côte M, Ménager MM, et al.: Inherited defects in lymphocyte cytotoxic activity. Immunol Rev. 2010; 235(1): 10-23. PubMed Abstract

6. Janka GE: Familial and acquired hemophagocytic lymphohistiocytosis. Annu Rev Med. 2012; 63: 233-46. PubMed Abstract | Publisher Full Text

7. Janka GE, Lehmberg K: Hemophagocytic syndromes--an update. Blood Rev. 2014; 28(4): 135-42.

PubMed Abstract | Publisher Full Text

8. de Saint Basile G, Ménasché G. Fischer A: Molecular mechanisms of biogenesis and exocytosis of cytotoxic granules. Nat Rev Immunol. 2010; 10(8): 568-79.

PubMed Abstract | Publisher Full Text

9. Behrens EM, Cron RQ: Kill or be killed. J Immunol. 2015; 194(11): 5041-3. PubMed Abstract | Publisher Full Text 
10. Jessen B, Kögl T, Sepulveda FE, et al.: Graded defects in cytotoxicity determine severity of hemophagocytic lymphohistiocytosis in humans and mice. Front Immunol. 2013; 4: 448.

PubMed Abstract | Publisher Full Text | Free Full Text

11. Sepulveda FE, Maschalidi S, Vosshenrich CAJ, et al:: A novel immunoregulatory role for NK-cell cytotoxicity in protection from HLH-like immunopathology in mice. Blood. 2015; 125(9): 1427-34.

PubMed Abstract | Publisher Full Text

12. Orange JS: Formation and function of the lytic NK-cell immunological synapse. Nat Rev Immunol. 2008; 8(9): 713-25.

PubMed Abstract | Publisher Full Text | Free Full Text

13. F Ritter AT, Asano Y, Stinchcombe JC, et al:: Actin depletion initiates events leading to granule secretion at the immunological synapse. Immunity. 2015 42(5): 864-76.

PubMed Abstract | Publisher Full Text | Free Full Text | F1000 Recommendation

14. Browne KA, Johnstone RW, Jans DA, et al.: Filamin (280-kDa actin-binding protein) is a caspase substrate and is also cleaved directly by the cytotoxic T lymphocyte protease granzyme B during apoptosis. J Biol Chem. 2000; 275(50): 39262-6.

PubMed Abstract | Publisher Full Text

15. F Rak GD, Mace EM, Banerjee PP, et al.: Natural killer cell lytic granule secretion occurs through a pervasive actin network at the immune synapse. PLoS Biol. 2011; 9(9): e1001151.

PubMed Abstract | Publisher Full Text | Free Full Text | F1000 Recommendation

16. Dustin ML, Long EO: Cytotoxic immunological synapses. Immunol Rev. 2010; 235(1): 24-34.

PubMed Abstract | Publisher Full Text | Free Full Text

17. F Stinchcombe JC, Majorovits E, Bossi G, et al.: Centrosome polarization delivers secretory granules to the immunological synapse. Nature. 2006; 443(7110): 462-5.

PubMed Abstract | Publisher Full Text | F1000 Recommendation

18. Voskoboinik I, Whisstock JC, Trapani JA: Perforin and granzymes: function, dysfunction and human pathology. Nat Rev Immunol. 2015; 15(6): 388-400. PubMed Abstract | Publisher Full Text

19. F Law RHP, Lukoyanova N, Voskoboinik I, et al: The structural basis for membrane binding and pore formation by lymphocyte perforin. Nature. 2010; 468(7322): 447-51.

PubMed Abstract | Publisher Full Text | F1000 Recommendation

20. F Baran K, Dunstone M, Chia J, et al:: The molecular basis for perforin oligomerization and transmembrane pore assembly. Immunity. 2009; 30(5): 684-95.

PubMed Abstract | Publisher Full Text | F1000 Recommendation

21. F Lopez JA, Susanto O, Jenkins MR, et al:: Perforin forms transient pores on the target cell plasma membrane to facilitate rapid access of granzymes during killer cell attack. Blood. 2013; 121(14): 2659-68. PubMed Abstract | Publisher Full Text | F1000 Recommendation

22. F Lopez JA, Jenkins MR, Rudd-Schmidt JA, et al.: Rapid and unidirectional perforin pore delivery at the cytotoxic immune synapse. J Immunol. 2013; 191(5): 2328-34.

PubMed Abstract | Publisher Full Text | F1000 Recommendation

23. F Keefe D, Shi L, Feske S, et al.: Perforin triggers a plasma membrane-repai response that facilitates CTL induction of apoptosis. Immunity. 2005; 23(3): 249-62.

PubMed Abstract | Publisher Full Text | F1000 Recommendation

24. Miaczynska M, Zerial M: Mosaic organization of the endocytic pathway. Exp Cell Res. 2002; 272(1): 8-14.

PubMed Abstract | Publisher Full Tex

25. F Thiery J, Keefe D, Boulant S, et al.: Perforin pores in the endosomal membrane trigger the release of endocytosed granzyme $B$ into the cytosol of target cells. Nat Immunol. 2011; 12(8): 770-7.

PubMed Abstract | Publisher Full Text | Free Full Text | F1000 Recommendation

26. F Feldmann J, Callebaut I, Raposo G, et al.: Munc13-4 is essential for cytolytic granules fusion and is mutated in a form of familial hemophagocytic lymphohistiocytosis (FHL3). Cell. 2003; 115(4): 461-73.

PubMed Abstract | Publisher Full Text | F1000 Recommendation

27. F Zur Stadt U, Schmidt S, Kasper B, et al.: Linkage of familial hemophagocytic ymphohistiocytosis (FHL) type-4 to chromosome $6 q 24$ and identification of mutations in syntaxin 11. Hum Mol Genet. 2005; 14(6): 827-34.

PubMed Abstract | Publisher Full Text | F1000 Recommendation

28. F Zur Stadt U, Rohr J, Seifert W, et al.: Familial hemophagocytic lymphohistiocytosis type 5 (FHL-5) is caused by mutations in Munc18-2 and impaired binding to syntaxin 11. Am J Hum Genet. 2009; 85(4): 482-92. PubMed Abstract | Publisher Full Text | Free Full Text | F1000 Recommendation

29. Côte M, Ménager MM, Burgess A, et al:: Munc18-2 deficiency causes familial hemophagocytic lymphohistiocytosis type 5 and impairs cytotoxic granule exocytosis in patient NK cells. J Clin Invest. 2009; 119(12): 3765-73. PubMed Abstract | Publisher Full Text | Free Full Text

30. Ménasché G, Pastural E, Feldmann J, et al:: Mutations in RAB27A cause Griscelli syndrome associated with haemophagocytic syndrome. Nat Genet. 2000; 25(2): 173-6.

PubMed Abstract | Publisher Full Text

31. Nagle DL, Karim MA, Woolf EA, et al:: Identification and mutation analysis of the complete gene for Chediak-Higashi syndrome. Nat Genet. 1996; 14(3): 307-11. PubMed Abstract | Publisher Full Text
32. Sepulveda FE, Burgess A, Heiligenstein X, et al.: LYST controls the biogenesis of the endosomal compartment required for secretory lysosome function. Traffic. 2015; 16(2): 191-203.

PubMed Abstract | Publisher Full Tex

33. Elstak ED, Neeft M, Nehme NT, et al.: The munc13-4-rab27 complex is specifically required for tethering secretory lysosomes at the plasma membrane. Blood. 2011; 118(6): 1570-8.

PubMed Abstract | Publisher Full Text

34. Boswell KL, James DJ, Esquibel JM, et al:: Munc13-4 reconstitutes calcium-dependent SNARE-mediated membrane fusion. J Cell Biol. 2012; 197(2): 301-12.

PubMed Abstract | Publisher Full Text | Free Full Text

35. Kurowska M, Goudin N, Nehme NT, et al.: Terminal transport of lytic granules to the immune synapse is mediated by the kinesin-1/SIp3/Rab27a complex. Blood. 2012; 119(17): 3879-89.

PubMed Abstract | Publisher Full Text | Free Full Text

36. Holt O, Kanno E, Bossi G, et al:: SIp1 and SIp2-a localize to the plasma membrane of CTL and contribute to secretion from the immunological synapse. Traffic. 2008; 9(4): 446-57.

PubMed Abstract | Publisher Full Text | Free Full Text

37. Ménasché G, Ménager MM, Lefebvre JM, et al:: A newly identified isoform of SIp2a associates with Rab27a in cytotoxic T cells and participates to cytotoxic granule secretion. Blood. 2008; 112(13): 5052-62.

PubMed Abstract | Publisher Full Text

38. F Stinchcombe JC, Salio M, Cerundolo V, et al:: Centriole polarisation to the immunological synapse directs secretion from cytolytic cells of both the innate and adaptive immune systems. BMC Biol. 2011; 9: 45

PubMed Abstract | Publisher Full Text | Free Full Text | F1000 Recommendation

39. F Bertrand $\mathrm{F}$, Müller $\mathrm{S}$, Roh $\mathrm{KH}$, et al: An initial and rapid step of lytic granule secretion precedes microtubule organizing center polarization at the cytotoxic T lymphocyte/target cell synapse. Proc Natl Acad Sci U S A. 2013; 110(15): 6073-8.

PubMed Abstract | Publisher Full Text | Free Full Text | F1000 Recommendation

40. F Choi PJ, Mitchison TJ: Imaging burst kinetics and spatial coordination during serial killing by single natural killer cells. Proc Natl Acad Sci U S A. 2013 110(16): 6488-93.

PubMed Abstract | Publisher Full Text | Free Full Text | F1000 Recommendation

41. F Vasconcelos Z, Müller S, Guipouy D, et al:: Individual Human Cytotoxic T yymphocytes Exhibit Intraclonal Heterogeneity during Sustained Killing. Cell Rep. 2015; 11(9): 1474-85.

PubMed Abstract | Publisher Full Text | F1000 Recommendation

42. Bechara E, Dijoud F, de Saint Basile G, et al.: Hemophagocytic lymphohistiocytosis with Munc13-4 mutation: a cause of recurrent fatal hydrops fetalis. Pediatrics. 2011; 128(1): e251-4. PubMed Abstract | Publisher Full Text

43. Levendoglu-Tugal O, Ozkaynak MF, LaGamma E, et al:: Hemophagocytic lymphohistiocytosis presenting with thrombocytopenia in the newborn. J Pediatr Hematol Oncol. 2002; 24(5): 405-9.

PubMed Abstract | Publisher Full Text

44. Odermatt B, Eppler M, Leist TP, et al.: Virus-triggered acquired immunodeficiency by cytotoxic T-cell-dependent destruction of antigen-presenting cells and lymph follicle structure. Proc Natl Acad Sci U S A. 1991; 88(18): 8252-6. PubMed Abstract | Publisher Full Text | Free Full Text

45. F Terrell CE, Jordan MB: Perforin deficiency impairs a critical mmunoregulatory loop involving murine $\mathrm{CD}^{+} \mathrm{T}$ cells and dendritic cells. Blood. 2013; 121(26): 5184-91.

PubMed Abstract | Publisher Full Text | Free Full Text | F1000 Recommendation

46. Sepulveda FE, Debeurme F, Ménasché G, et al.: Distinct severity of HLH in both human and murine mutants with complete loss of cytotoxic effector PRF1, RAB27A, and STX11. Blood. 2013; 121(4): 595-603.

PubMed Abstract | Publisher Full Text

47. F Waggoner SN, Cornberg M, Selin LK, et al.: Natural killer cells act as rheostats modulating antiviral T cells. Nature. 2012; 481(7381): 394-8. PubMed Abstract | Publisher Full Text | Free Full Text | F1000 Recommendation

48. F Lang PA, Lang KS, Xu HC, et al:: Natural killer cell activation enhances immune pathology and promotes chronic infection by limiting $C D 8^{+} \mathrm{T}$-cell immunity. Proc Natl Acad Sci U S A. 2012; 109(4): 1210-5. PubMed Abstract | Publisher Full Text | Free Full Text | F1000 Recommendation

49. F Kögl T, Müller J, Jessen B, et al:: Hemophagocytic lymphohistiocytosis in syntaxin-11-deficient mice: T-cell exhaustion limits fatal disease. Blood. 2013; 121(4): 604-13.

PubMed Abstract | Publisher Full Text | F1000 Recommendation

50. F Faroudi M, Utzny C, Salio M, et al:: Lytic versus stimulatory synapse in cytotoxic $T$ lymphocyte/target cell interaction: manifestation of a dual activation threshold. Proc Natl Acad Sci U S A. 2003; 100(24): 14145-50. PubMed Abstract | Publisher Full Text | Free Full Text | F1000 Recommendation

51. F Jenkins MR, Rudd-Schmidt JA, Lopez JA, et al:: Failed CTL/NK cell killing and cytokine hypersecretion are directly linked through prolonged synapse time. J Exp Med. 2015; 212(3): 307-17.

PubMed Abstract | Publisher Full Text | Free Full Text | F1000 Recommendation

52. Strauss $\mathrm{R}$, Neureiter $\mathrm{D}$, Westenburger $\mathrm{B}$, et al:: Multifactorial risk analysis of bone marrow histiocytic hyperplasia with hemophagocytosis in critically ill medical patients--a postmortem clinicopathologic analysis. Crit Care Med. medical patients--a pos

PubMed Abstract | Publisher Full Text 
53. F Zoller EE, Lykens JE, Terrell CE, et al.: Hemophagocytosis causes a Fonsumptive anemia of inflammation. J Exp Med. 2011; 208(6): 1203-14. PubMed Abstract | Publisher Full Text | Free Full Text | F1000 Recommendation

54. de Jesus AA, Canna SW, Liu Y, et al:: Molecular mechanisms in genetically defined autoinflammatory diseases: disorders of amplified danger signaling. Annu Rev Immunol. 2015; 33: 823-74. PubMed Abstract | Publisher Full Text | Free Full Text

55. F Krebs P, Crozat K, Popkin D, et al.: Disruption of MyD88 signaling suppresses hemophagocytic lymphohistiocytosis in mice. Blood. 2011; 117(24): 6582-8. PubMed Abstract | Publisher Full Text | Free Full Text | F1000 Recommendation

56. F Milner JD, Orekov T, Ward JM, et al.: Sustained IL-4 exposure leads to a novel pathway for hemophagocytosis, inflammation, and tissue macrophage accumulation. Blood. 2010; 116(14): 2476-83. PubMed Abstract | Publisher Full Text | Free Full Text | F1000 Recommendation

57. F Behrens EM, Canna SW, Slade K, et al:: Repeated TLR9 stimulation results in macrophage activation syndrome-like disease in mice. J Clin Invest. 2011; 121(6): 2264-77

PubMed Abstract | Publisher Full Text | Free Full Text | F1000 Recommendation

58. Pachlopnik Schmid J, Canioni D, Moshous D, et al:: Clinical similarities and differences of patients with X-linked lymphoproliferative syndrome type 1 (XLP-1/SAP deficiency) versus type 2 (XLP-2/XIAP deficiency). Blood. 2011; 117(5): 1522-9.

PubMed Abstract | Publisher Full Text

59. Nichols KE, Harkin DP, Levitz $\mathrm{S}$, et al:: Inactivating mutations in an SH2 domain-encoding gene in $\mathbf{X}$-linked lymphoproliferative syndrome. Proc Nat Acad Sci U S A. 1998; 95(23): 13765-70. PubMed Abstract | Publisher Full Text | Free Full Text

60. Coffey AJ, Brooksbank RA, Brandau O, et al:: Host response to EBV infection in $\mathrm{X}$-linked lymphoproliferative disease results from mutations in an SH2-domain encoding gene. Nat Genet. 1998; 20(2): 129-35 PubMed Abstract | Publisher Full Text

61. Sayos J, Wu C, Morra M, et al:: The X-linked lymphoproliferative-disease gene product SAP regulates signals induced through the co-receptor SLAM. Nature. 1998; 395(6701): 462-9.

PubMed Abstract | Publisher Full Tex

62. Palendira U, Low C, Chan A, et al: Molecular pathogenesis of EBV susceptibility in XLP as revealed by analysis of female carriers with heterozygous expression of SAP PLOS Biol 2011: 9(11): 1001187. PubMed Abstract | Publisher Full Text | Free Full Text

63. Tangye SG: XLP: clinical features and molecular etiology due to mutations in SH2D1A encoding SAP. J Clin Immunol. 2014; 34(7): 772-9. PubMed Abstract | Publisher Full Text

64. F Rigaud S, Fondanèche $\mathrm{M}$, Lambert $\mathrm{N}$, et al:: XIAP deficiency in humans causes an X-linked lymphoproliferative syndrome. Nature. 2006; 444(7115): 110-4. PubMed Abstract | Publisher Full Text | F1000 Recommendation
65. Chung BK, Tsai K, Allan LL, et al:: Innate immune control of EBV-infected B cells by invariant natural killer T cells. Blood. 2013; 122(15): 2600-8. PubMed Abstract | Publisher Full Text

66. F Yabal M, Müller N, Adler $\mathrm{H}$, et al:: XIAP restricts TNF- and RIP3-dependent cell death and inflammasome activation. Cell Rep. 2014; 7(6): 1796-808. PubMed Abstract | Publisher Full Text | F1000 Recommendation

67. F Chia J, Yeo KP, Whisstock JC, et al.: Temperature sensitivity of human perforin mutants unmasks subtotal loss of cytotoxicity, delayed FHL, and predisposition to cancer. Proc Natl Acad Sci U S A. 2009; 106(24): predisposit

PubMed Abstract | Publisher Full Text | Free Full Text | F1000 Recommendation

68. Nagafuji K, Nonami A, Kumano T, et al.: Perforin gene mutations in adult-onset hemophagocytic lymphohistiocytosis. Haematologica. 2007; 92(7): 978-81.

PubMed Abstract | Publisher Full Text

69. Mancebo E, Allende LM, Guzmán M, et al.: Familial hemophagocytic lymphohistiocytosis in an adult patient homozygous for A91V in the perforin gene, with tuberculosis infection. Haematologica. 2006; 91(9): 1257-60. PubMed Abstract

70. F Shabbir M, Lucas J, Lazarchick J, et al:: Secondary hemophagocytic syndrome in adults: a case series of 18 patients in a single institution and a review of literature. Hematol Oncol. 2011; 29(2): 100-6. PubMed Abstract | Publisher Full Text | F1000 Recommendation

71. F Zhang M, Behrens EM, Atkinson TP, et al:: Genetic defects in cytolysis in macrophage activation syndrome. Curr Rheumatol Rep. 2014; 16(9): 439. PubMed Abstract | Publisher Full Text | F1000 Recommendation

72. $\mathrm{F}$ Zhang $\mathrm{K}$, Jordan MB, Marsh RA, et al:: Hypomorphic mutations in PRF1, MUNC13-4, and STXBP2 are associated with adult-onset familial HLH. Blood. 2011; 118(22): 5794-8.

PubMed Abstract | Publisher Full Text | Free Full Text | F1000 Recommendation

73. F Zhang K, Chandrakasan S, Chapman H, et al:: Synergistic defects of different molecules in the cytotoxic pathway lead to clinical familial hemophagocytic lymphohistiocytosis. Blood. 2014; 124(8): 1331-4. PubMed Abstract | Publisher Full Text | Free Full Text | F1000 Recommendation

74. F Romberg N, Al Moussawi K, Nelson-Williams C, et al:: Mutation of NLRC4 causes a syndrome of enterocolitis and autoinflammation. Nat Genet. 2014; 46(10): 1135-9.

PubMed Abstract | Publisher Full Text | Free Full Text | F1000 Recommendation

75. F Canna SW, de Jesus AA, Gouni S, et al:: An activating NLRC4 nflammasome mutation causes autoinflammation with recurrent macrophage activation syndrome. Nat Genet. 2014; 46(10): 1140-6. PubMed Abstract | Publisher Full Text | Free Full Text | F1000 Recommendation

76. F Kitamura A, Sasaki Y, Abe T, et al:: An inherited mutation in NLRC4 causes autoinflammation in human and mice. J Exp Med. 2014; 211(12): 2385-96. PubMed Abstract | Publisher Full Text | Free Full Text | F1000 Recommendation 


\section{Open Peer Review}

\section{Current Peer Review Status:}

\section{Version 1}

Reviewer Report 30 September 2015

https://doi.org/10.5256/f1000research.7256.r10629

(C) 2015 Voskoboinik I. This is an open access peer review report distributed under the terms of the Creative Commons Attribution License, which permits unrestricted use, distribution, and reproduction in any medium, provided the original work is properly cited.

\section{Ilia Voskoboinik}

Cancer immunology Program, Peter MacCallum Cancer Centre, East Melbourne, Australia

Competing Interests: No competing interests were disclosed.

I confirm that I have read this submission and believe that I have an appropriate level of expertise to confirm that it is of an acceptable scientific standard.

Reviewer Report 30 September 2015

https://doi.org/10.5256/f1000research.7256.r10627

(C) 2015 Dupré L. This is an open access peer review report distributed under the terms of the Creative Commons Attribution License, which permits unrestricted use, distribution, and reproduction in any medium, provided the original work is properly cited.

\section{Loïc Dupré}

Centre de Physiopathologie de Toulouse Purpan, INSERM, UMR1043, Toulouse, France

Competing Interests: No competing interests were disclosed.

I confirm that I have read this submission and believe that I have an appropriate level of expertise to confirm that it is of an acceptable scientific standard. 
The benefits of publishing with F1000Research:

- Your article is published within days, with no editorial bias

- You can publish traditional articles, null/negative results, case reports, data notes and more

- The peer review process is transparent and collaborative

- Your article is indexed in PubMed after passing peer review

- Dedicated customer support at every stage

For pre-submission enquiries, contact research@f1000.com 